\title{
CONTROVERSY/COMMENTARY
}

\section{The Cult of Collaboration in Public Policy}

\author{
Janine O'Flynn \\ Australian National University
}

\begin{abstract}
A 'cult of collaboration' is emerging in Australian public policy circles. In this article I argue this reflects a misunderstanding of the concept and its distinctive characteristics. Here I reintroduce collaboration vis-à-vis other forms of 'working together' and question whether we have taken a collaborative turn in public policy. In doing so I hope to contribute to a debate on the relevance of collaboration for public policy.
\end{abstract}

Key words: collaboration, public policy, Australia

Collaboration has become du jour in Australian policy circles. Collaborative governance reared its head at the 2020 Summit and the Future Summit in 2008 and, in other parts of the world, the cult of collaboration has taken hold. With all the talk about collaboration it would be easy to say we have moved on from bureaucratic fiefdoms and competition; that a collaborative turn has taken place. Caution is, however, needed before we draw such conclusions. Part of the current popularity of 'collaboration' has been the loose way in which it has been used by both academics and practitioners: suddenly everything is collaborative. With this we run the risk of creating yet another fad word in government circles: a cult of collaboration where everyone believes but few practice. In the midst of the growing interest in collaboration it is appropriate, I argue, to pause and look again at what is actually meant by the term. This will allow us to more realistically appraise what is going on in the real world of public policy.

\section{Why Collaboration is King}

The current obsession with collaboration may lead us to conclude that a fundamental change is taking place in the way in which government and public sector organisations (PSOs) operate. The factors driving the cult of collab- oration are wide and varied eg, issues are seen as increasingly complex and cross-cutting or 'wicked' (Huxham, Vangen and Eden 2000; APSC 2007); and PSOs have access to an ever-dwindling pool of resources (Lowndes and Skelcher 1998; Economist Intelligence Unit 2007). Such drivers make collaboration attractive because it may (i) encourage trust and reduce conflict; (ii) unlock distinctive competencies in other sectors; and (iii) deliver a transformational approach to improvement in public services (Entwistle and Martin 2005); in turn, collaboration may offer much in the way of improving effectiveness, efficiency, and quality. In policy terms, the obsession with collaboration has resulted in two responses (Bryson, Crosby and Middleton Stone 2006): collaboration becomes the latest 'one best way', the Holy Grail of operating; or the last resort of governments and PSOs when nothing else works. In other words, organisations fail into collaboration. Neither provides an especially convincing basis for investing in collaborative endeavours.

The cult of collaboration has been fuelled by consultants who pronounce that PSOs must develop 'perpetual collaboration' capabilities to face the demands of the $21^{\text {st }}$ century (Cortada et al. 2008), and by prominent figures in the policy world. In Australia, for example, much of the collaboration imperative 
came from Prime Minister and Cabinet under the leadership of Peter Shergold who, truth be told, has been cautious about overstating the rate of progress (see Shergold 2008). This trickled into the Management Advisory Committee (MAC 2004) manifesto Connecting Government, and the treaty on 'wicked problems' produced by the Australian Public Service Commission (APSC 2007). Academics too have been won-over by the promise of collaboration with several prominent writers positioning it as a key feature of the post-New Public Management paradigm (see Denhardt and Denhardt 2000; Osborne 2006). Such ideas come together in notions such as collaborative public management which has been described as 'the process of facilitating and operating in multiorganisational arrangements in order to remedy problems that cannot be solved - or solved easily - by single organisation' (McGuire 2006:3). Collaboration, it seems, is King in a turbulent world where governments don't have all the answers to complex challenges, and where there is some impetus to move beyond both bureaucracy and markets.

\section{Collaboration Discovered?}

Given the recent flurry about collaboration it would be easy to conclude that public policy experts have discovered it; but collaboration is nothing new in this world (see McGuire 2006). Writing in The Academy of Management Journal more than three decades ago Schermerhorn (1975) noted that inter-agency cooperation was developing as a panacea for the 'coordination gap' in social services, the product of duplication, overlap, and fragmentation in an increasingly turbulent and complex environment. There are, of course, striking similarities with the current discourse on collaboration. In an ideal world the current interest in collaboration would lead public policy scholars and practitioners into more fertile areas to learn important lessons. As the editors of a recent special issue lamented, however, 'collaborative public management' is largely studied without the benefit of examining the literature in related fields (O'Leary, Gerard and Bingham 2006).
Indeed, in their concluding points Bingham and O'Leary (2006:161) commented, 'we tend to play cooperatively each with our own set of blocks ... we do not generally pool our blocks to build a common structure collaboratively'. Unfortunately, it is now generally accepted that there is little cross-pollination or collaboration between the fields of study interested in collaboration (eg, Hardy, Phillips and Lawrence 2003; Huxham and Vangen 1998, cited in Williams 2002). Remarkably, for all the talk of collaboration, there seems to be little interdisciplinary collaboration done in the scholarly world.

Outside of the public policy world, collaboration has been a central concern for many fields of study. A fairly unscientific survey shows collaboration to be a strategic response to resource dependencies, an approach for pooling resources or leveraging new ones, a means of reducing risk, a strategy for entering new markets, a means of reducing transaction costs, a reaction to increasingly complex and turbulent environments, or a tool for (re)integration in fragmented domains (see, for example, Lowndes and Skelcher 1998; Lawrence, Phillips and Hardy 1999; Bryson, Crosby and Middleton Stone 2006). There are several untapped areas of knowledge for public policy experts including the potential goldmine of work on joint ventures, strategic alliances, and hybrids which ask the fundamental question: 'how do we organise to achieve our goals?' Writing on interorganisational trust and the costs of working together (eg, White's 2005 work on cooperation costs) is also informative. By not engaging, we tend to miss sage advice especially when it comes to the dangers of seeing collaboration as a panacea (eg, Bryson, Crosby and Middleton Stone 2006). Huxham in her extensive work on collaboration has, for a long time, warned against a blinkered view: 'Collaboration is not a panacea for tackling all organisational activities. Most of what organisations strive to achieve is, and should be, done alone' (Huxham 1996:3). Lundin (2007) makes a similar point, noting that forms of engagement should be driven by task complexity; thus, using collaborative approaches for simple tasks is neither useful, nor likely to yield quantifiable benefits. 


\section{Collaboration: A (Re)Introduction}

Collaboration has become so central to public policy discourse that few now bother to explain what they even mean by it. Of course, formal definitions abound in the diverse literature on the topic, but it is used fairly loosely in the public policy world. The trend toward calling all forms of working together 'collaboration' is problematic as it glosses over the diverse array of mechanisms for working together and the relative appropriateness of these for different tasks and contexts.

The relative ambiguity of the term is clear in recent prominent policy documents: here collaboration is central, but unexplained. In the MAC (2004) manifesto, collaboration is the key to 'connecting government' with much made of the need to develop intra- and interorganisational collaboration, to create a 'culture of collaboration' (p.10), to orient toward collaborative approaches, to shift from contract-based service models toward more collaborative ones, and for Secretaries to model collaborative behaviour. Collaboration, however, is never defined or explained in any meaningful way, but it is clear that everyone must be collaborative. In Tackling Wicked Problems (APSC 2007), collaboration is the means of solving complex, inter-agency, interjurisdictional puzzles. Yet again, collaboration itself is never really explained. Similar problems emerge in the academic literature including much of the work on collaborative governance, where collaboration is loosely employed. Both the prominence and the considerable slipperiness of the term mean that it warrants attention in its own right. Without delving into the mounds of literature on how, when, and why to do it, my main aim here is to reintroduce the concept and its distinctive characteristics.

Given the depth and breadth of the literature on collaboration it has been defined and deployed in many different ways. A relatively straightforward definition is provided by Himmelman (2002:3): collaboration is 'a process in which organisations exchange information, alter activities, share resources, and enhance each other's capacity for mutual benefit and a common purpose by sharing risks, responsibilities, and rewards'. Others have defined collaboration as an 'interorganisational relationship that relies on neither market nor hierarchical mechanism of control but is instead negotiated in an ongoing communicative process' (Lawrence, Phillips and Hardy 1999:481). Multiple typologies exist but we can point to some similarities: collaboration sits at one end of a spectrum of ways in which organisations might work together; it is more strategic (Head 2004, 2006); it focuses on shared goals (Economist Intelligence Unit 2007) and culture (Axelrod 1984, 1997); and it is voluntary - Hardy, Phillips and Lawrence (2003) make the point that collaboration is different to cooperation which can be purchased (eg, from a supplier) or demanded (eg, by a government organisation).

A useful typology is provided by Mattessich and Monsey (1992:39) who set out different forms based on the key elements of vision and relationship, structure, responsibilities and communication, authority and accountability, and resources and reward. Cooperation, then, is described as an informal relationship where there is no common mission/vision, where information is shared on an as needed basis, authority remains vested in the separate organisations, there is little risk, and resources and rewards remain separate. Coordination involves more formality, missions are compatible and this requires common planning and more formal communication; risk increases due to the increased intensity of the relationship. Collaboration is a more 'durable and pervasive relationship' (p.39) involving new structures, a common mission, shared planning, formal communication across multiple levels, pooling and jointly acquiring resources, shared rewards, and more risk.

Himmelman (2002:1-5) provides another which distinguishes networking, coordinating, cooperating and collaboration. ${ }^{1}$ Here the distinctions between forms are made relative to the different commitments of trust, time and turf. The least formal is networking where information is exchanged for mutual benefit. Often the choice of this strategy reflects limited time, low trust or a reluctance to concede turf. More formal linkages occur with coordinating and here information is exchanged and 
activities altered so the parties can pursue mutual benefit and achievement of common purpose. Coordinating involves more time and higher trust than networking, but the parties do not concede any turf. Where the intensity of commitments increase and more formal agreements are introduced, cooperating emerges as a strategy for working together. This involves higher levels of trust and time in relation to networking and coordinating and each party will, at least, provide access to its turf. Finally, where the parties develop a willingness to enhance each others capacity for mutual benefit and common purpose, collaboration occurs. Here the parties share risks, responsibilities and rewards; they have high levels of trust, large time commitments, and they share turf.

Collaboration then is just one way in which organisations might work together. Others are important and, most likely they better reflect practice in the public policy world where cooperation is often purchased or demanded, where turf is guarded, and where resources and rewards largely remain tied to autonomous organisations. Finding examples of true collaboration will be, of course, an empirical question for researchers.

\section{Now What?}

The purpose of this discussion was to more clearly illuminate what collaboration is and what it is not. This is not intended to be a purely academic exercise, but to provide a basis for continued debate on the reality of collaboration in public policy. It is too easy to be taken by the promise of collaboration; to cheer at the Emperor in his new clothes. However this disguises a reality of public policy which is far from that, where organisations engage using a range of engagement modes, some more or less appropriate than others. What we are seeing is a phenomenon where everyone is talking about collaboration, but significant questions remain about whether they are actually doing collaboration. As Hardy and Phillips (1998:217) have cautioned, 'surface dynamics are not necessarily an accurate description of what is going on beneath'. Part of the job for academics will be to delve beneath these surface dynamics, beneath the current sermonising about collaboration to see what is really going on, and cast a critical eye over the rhetoric of collaboration. This does not, of course, mean there is no such thing as collaboration in practice, but that we need to be encouraging dialogue between practitioners and scholars on the different forms of working together that are taking place.

In this short piece I sought to provide a reminder to public policy experts - both in the academy and in the field - about what collaboration is. I hope this will provide a buffer of sorts against the cult of collaboration which is sweeping the public policy world. In the end, if we fail to distinguish it from the other ways of working together, we end up with much collaborative talk, but not much in terms of action.

\section{Note}

Janine O'Flynn is co-editor of a recent monograph Collaborative Governance: A New Era of Public Policy in Australia? published by the Australia and New Zealand School of Government. Readers can access the monograph, free of charge, at http://epress.anu.edu.au/collab _gov_citation.html.

\section{Endnote}

1. Himmelman argues these may also be considered developmental stages in an interorganisational relationship.

\section{References}

APSC [Australian Public Service Commission]. 2007. Tackling Wicked Problems: A Public Policy Perspective. Canberra: Australian Government.

Axelrod, R. 1984. The Evolution of Cooperation. New York: Basic Books.

Axelrod, R. 1997. The Complexity of Cooperation: Agent-Based Models of Competition and Collaboration. Princeton, New Jersey: Princeton University Press.

Bingham, L. and R. O'Leary. 2006. 'Conclusion: Parallel Play, Not Collaboration: Missing 
Questions, Missing Connections.' Public Administration Review 66(s1):161-167.

Bryson, J.M., B.C. Crosby and M. Middleton Stone. 2006. 'The Design and Implementation of Cross-Sector Collaborations: Propositions from the Literature.' Public Administration Review 66(s1):44-55.

Cortada, J.W., S. Dijkstra, G.M. Mooney and T. Ramsey. 2008. Government 2020 and the Perpetual Collaboration Mandate: Six Worldwide Drivers Demand Customized Strategies. New York: IBM Institute for Business Value, IBM Global Services.

Denhardt, R.B. and J.V. Denhardt. 2000. 'The New Public Service: Serving Rather than Steering.' Public Administration Review 60(6):549-559.

Economist Intelligence Unit. 2007. Collaboration: Transforming the Way Business Works. The Economist, London. URL:<http://www.eiu.com/site _info.asp?info_name $=$ Collaboration_Transform ing_the_way_business_works\& $\mathrm{rf}=0>$. Consulted 7 April 2008.

Entwistle, T. and S. Martin. 2005. 'From Competition to Collaboration in Public Service Delivery: A New Agenda for Research.' Public Administration 83(1):233-242.

Hardy, C. and N. Phillips. 1998. 'Strategies of Engagement: Lessons from the Critical Examination of Collaboration and Conflict in an Interorganizational Domain.' Organization Studies 9(2):217230.

Hardy, C., N. Phillips and T.B. Lawrence. 2003. 'Resources, Knowledge and Influence: The Organizational Effects of Interorganizational Collaboration.' Journal of Management Studies, 40(2):321-347.

Head, B. 2004. Collaboration - What We Already Know, and How to Do It Better. Australian Research Alliance for Children and Youth, 20 January. URL: $<$ http://www.aracy.org.au/> . Consulted 7 April 2007.

Head, B. 2006. Effective Collaboration. Australian Research Alliance for Children and Youth, July. URL:<http://www.aracy.org.au/>. Consulted 7 April 2007.

Himmelman, A.T. 2002. Collaboration for a Change: Definitions, Decision-Making Models, Roles, and Collaboration Process Guide. Minneapolis: Himmelman Consulting.

Huxham, C., ed. 1996. Creating Collaborative Advantage. London: Sage.

Huxham, C. and S. Vangen. 2004. 'Doing Things Collaboratively: Realizing the Advantage or
Succumbing to Inertia?' Organizational Dynamics 33(3): 190-201.

Huxham, C., S. Vangen and C. Eden. 2000. 'The Challenge of Collaborative Governance.' Public Management Review 2(2):337-358.

Lawrence, T.B., N. Phillips and C. Hardy. 1999. 'Watching Whale Watching: Exploring the Discursive Foundations of Collaborative Relationships.' Journal of Applied Behavioral Science 35(4):479-502.

Lowndes, V. and C. Skelcher. 1998. 'The Dynamics of Multi-Organizational Partnerships: An Analysis of Changing Modes of Governance.' Public Administration 76(2):313-333.

Lundin, M. 2007. 'When Does Cooperation Improve Public Policy Implementation?' The Policy Studies Journal 35(4):629-652.

MAC [Management Advisory Committee]. 2004. Connecting Government: Whole of Government Responses to Australia's Priority Challenges. Canberra: Australian Government.

Mattessich, P.W. and B.R. Monsey. 1992. Collaboration: What Makes It Work. Minnesota: Amherst H. Wilder Foundation, St Paul.

McGuire, M. 2006. 'Collaborative Public Management: Assessing What We Know and How We Know It.' Public Administration Review 66(s1):33-43.

O'Leary, R. and L.B. Bingham. 2007. A Manager's Guide to Resolving Conflicts in Collaborative Networks. Washington D.C.: IBM Center for The Business of Government.

O'Leary, R., C. Gerard and L.B. Bingham. 2006. 'Introduction to the Symposium on Collaborative Public Management.' Public Administration Review 66(s1):6-9.

Osborne, S. 2006. 'The New Public Governance?' Public Management Review 8(3):377-387.

Schermerhorn, J.R. 1975. 'Determinants of Interorganizational Cooperation.' Academy of Management Journal 18(4):846-856.

Shergold, P. 2008. 'Governing through Collaboration.' In Collaborative Governance: A New Era of Public Policy in Australia?, J. O'Flynn and J. Wanna. Canberra: The Australia and New Zealand School of Government, The Australian National University E-Press, 13-22.

White, S. 2005. 'Cooperation Costs, Governance Choice and Alliance Evolution.' Journal of Management Studies 42(7):1383-1412.

Williams, P. 2002. 'The Competent Boundary Spanner.' Public Administration 80(1):103124. 